\title{
Impact of pedoclimatic and agricultural conditions on sunflower seeds characteristics in relation to the dehulling process
}

\author{
Sylvie Dauguet ${ }^{1, \star}$, Frédéric Fine ${ }^{1}$, Céline Guillemain $^{1}$, Patrick Carré ${ }^{2}$, André Merrien $^{3}$, \\ Mohammed Krouti ${ }^{3}$ and Luc Champolivier ${ }^{4}$ \\ ${ }^{1}$ CETIOM, 11 rue Monge, 33600 Pessac, France \\ 2 CREOL, 11 rue Monge, 33600 Pessac, France \\ ${ }^{3}$ CETIOM, Analysis Laboratory, 270 av de la Pomme de Pin, Ardon, 45166 Olivet, France \\ ${ }^{4}$ CETIOM, Centre INRA, bat. AGIR 31326 Castanet Tolosan, France
}

Received 27 September 2014 - Accepted 4 November 2014

\begin{abstract}
Dehulling sunflower seeds can increase meal protein content by up to 35-36\%. However, high variability in seed quality constitutes an obstacle to optimizing the dehulling process. This study has sought to identify the parameters that influence the protein content of sunflower seeds and the ease with which they can be dehulled. Genetic, climatic and crop management effects were studied using seed samples taken from farmers' fields in south-west France. Soil and climatic effects were revealed to be important for protein content and ease of dehulling (hullability). Some cultivars were found to be significantly more difficult to dehull than others. No relationship was observed between oil content and protein content expressed as a proportion of DDM (defatted dry matter), but there was a significant negative linear relationship between hullability and oil content. Due to the wide range of locations and agricultural practices encountered in the farmers' fields, it was not possible to verify with confidence the influence of other interactions such as nitrogen fertilization and the potential fertility of the fields. This work nevertheless showed that locality and growing conditions affect the quality of sunflower seeds. This variability in quality could be measured by crushers in order to optimize the dehulling process and thereby produce a meal of consistent quality, with a guaranteed protein content.
\end{abstract}

Keywords: Sunflower / seed quality / dehulling / protein / hullability / meal

Résumé - Impact des conditions pédoclimatiques et des pratiques agricoles sur la qualité des graines de tournesol en relation avec le procédé de décorticage. Impact des conditions pédoclimatiques et agricoles sur les caractéristiques des graines de tournesol en relation avec le procédé de décorticage. Le décorticage des graines de tournesol peut augmenter la teneur en protéines dans le tourteau jusqu'à 35-36\% sur matière brute, mais la grande variabilité de la qualité des graines est un problème pour optimiser le processus industriel. Le but de cette étude était d'observer les paramètres influençant la teneur en protéines et l'aptitude au décorticage des graines de tournesol. Nous avons étudié les effets génétiques, climatiques, et de gestion des cultures avec des échantillons provenant d'une enquête dans des parcelles d'agriculteurs dans le Sud-Ouest de la France. Le pédoclimat avait un important effet sur la teneur en protéines et l'aptitude au décorticage. Certains cultivars étaient beaucoup plus difficiles à décortiquer. Aucune relation n'a été observée entre la teneur en protéines exprimée sur MSD (matière sèche déshuilée) et la teneur en huile, mais une relation négative significative existe entre l'aptitude au décorticage et la teneur en huile. Les autres interactions n'ont pas pu être clairement démontrées (fertilisation azotée, potentiel de rendement des parcelles) à cause de la grande diversité des situations et des pratiques agricoles. Ce travail a montré que l'origine des lots pourrait affecter la qualité des graines de tournesol. La variabilité de cette qualité pourrait être mesurée par des triturateurs afin d'optimiser le processus de décorticage pour produire les tourteaux de qualité conforme, avec une teneur garantie en protéines.

Mots clés : Tournesol / qualité des graines / aptitude au décorticage / protéines / tourteau

^ Correspondence: dauguet@cetiom.fr 


\section{Introduction}

The sunflower market's current economic situation, alongside rising energy costs, renders profitable the process of dehulling prior to crushing. Various qualities of sunflower meals are therefore produced in France: $28 \%, 32 \%$ and $36 \%$ of proteins for non-dehulled and partially dehulled seeds (a greater dehulling rate in the third case), expressed on raw matter. In the dehulling process, the extracted hulls can be burned in biomass boilers to produce steam on-site, the efficiency of which varies according to the type of boiler technology employed (Tostain et al., 2012). This contributes to improving the competitiveness of sunflower seeds as well as decreasing their carbon footprint.

Whole Seed Sunflower Meal (WSSM) has both a relatively high proportion of poorly digestible fiber (which comes from the hulls; they account for approximately $25 \%$ of the seed's mass and $45 \%$ of the mass of the meal), and a relatively low protein content: only 27-29\% of raw matter (Dauguet et al., 2012a). These are quite attractive characteristics for animals like ruminants, and rabbits, as well as some poultry that require low-energy nutrition. But this WSSM is not suitable as a feed for animals that require higher energy and protein contents like dairy cows, pigs and chickens (Peyronnet et al., 2012).

Dehulling sunflower seeds prior to oil extraction results in meals with higher protein content and reduced fiber. Partially Dehulled Sunflower Meal (PDSM) with 36\% protein content (wet basis) seems very well adapted to the diets of egg-laying poultry (Peyronnet et al., 2012). The process is competitive since the higher market value of PDSM and hulls as compared to WSSM offsets the cost of dehulling.

This improvement in the meals and the industrial process could be further enhanced through improvements in the quality of seeds, notably in the protein content of the defatted dry matter and the ease with which hulls can be removed from seeds (or dehulling ability, frequently referred to as 'hullability', which is assessed as the percentage mass of extracted hulls from an initial mass of seeds using a standard dehulling process). Though extracted hulls can be recovered for steamenergy production in situ, this end-use is rapidly exhausted since oil mills have a relatively low steam power requirement. This being the case, it is more profitable to extract the minimum amount of hulls necessary to produce the maximum amount of meal that meets the set protein content requirement. Moreover, increasing the dehulling rate (proportion of extracted hulls to the initial mass of whole seeds) generates an increased likelihood of oil losses in the extracted hulls; this is both an economic loss and a danger for the environment since the burning of oil produces harmful compounds.

Dehulled meals must have a consistent protein content. So, if incoming sunflower seeds have high protein content (expressed as a proportion of Defatted Dry Matter, DDM), the dehulling rate can be lowered and a greater quantity of meal produced from an initial mass of seeds; the obverse also applies and for this reason consistency in the protein content of sunflower seeds is also an essential factor. At the entrance of a factory, the variability of seeds quality may be substantial, with protein content varying between $29.8 \%$ and $35.8 \%$ on DDM, and with hullability varying from $9.2 \%$ to $18.4 \%$ (Dauguet et al., 2012b). Indeed, when the protein content in incoming seeds is highly variable (high standard deviation), the targeted average protein content of the meal has to be increased in order to ensure that $95 \%$ of the delivered meal reaches the required protein level, 35 or $36 \%$ according to the specifications; this implies that the dehulling rate has to be raised. Conversely, when the incoming seeds have a relatively homogeneous protein content, the dehulling rate can be adjusted to a lower level (Dauguet et al., 2012b). This explains why high variability in seed quality is a problem for optimizing the industrial process (Tostain et al., 2012).

Poor hullability can compromise the chances of producing a meal that reaches the required protein level. Hullability increases with the size of seeds and decreases with their oil content, which are varietal characteristics (Denis et al., 1994; Evrard et al., 1996; Nel, 2001; Sharma et al., 2009). Other studies have shown that soil and climate conditions, as well as agricultural practices, have a significant impact on hullability (Denis and Vear, 1994; Merrien et al., 1992; Nel, 2001) and protein content (Nel, 2001; Oraki et al., 2011). A multi-year survey on sunflower seeds showed that the protein content of sunflower seeds produced in France during the period 20032010 ranged from 31.7 to $34.4 \%$ of DDM (Borredon et al., 2011). So, from the industrial point of view, the variability of sunflower seed quality is an important issue that requires further investigation for improved control.

This particular study has sought to identify the parameters that influence the protein content and hullability of sunflower seeds. We studied genetic, climatic and crop management effects on these characteristics, with seed samples sourced during a two-year study of farmers' fields across a large agricultural area of south-west France.

\section{Materials and methods}

Samples: 156 seed samples were collected from a network of farmers' fields that had been built up within the context of a project aimed at improving sunflower oil yields at a production-area scale. Each sample was taken from an individual field. The hybrids included in this study were the oleic type: NK Countri and PR64H32 in 2008, and NK Countri and NK Ferti in 2009. Selected fields varied from low to high yield potential. Questionnaires were completed on farming practices and growing conditions for each field (amount of fertilizer applied, sowing date, plant density, yield, soil depth etc.).

Chemical analyses: For each seed sample collected, oil content, expressed as a proportion of dry matter (DM), was measured by nuclear magnetic resonance (NF EN ISO 10565) and protein content, expressed as a proportion of DDM was obtained by the Dumas method (NF V18-120): Protein $(\% \mathrm{DDM})=$ Protein $(\% \mathrm{DM}) /(1-$ Oil $(\% \mathrm{DM}))$. The thousand seeds weight (TSW) was also measured on clean dry grain.

Hullability determination: Theoretically, hullability should be expressed as the mass of hulls removed by a standard procedure as a proportion of the total mass of the seeds' hulls. A previous unpublished study carried out in our laboratory showed that measuring the total hull mass of the seeds brings little information and that the "rate of hulls" i.e., the mass of extracted hulls as a proportion of the mass of seeds (which is easier to measure) is a good indicator of the seeds' hullability. So, what 


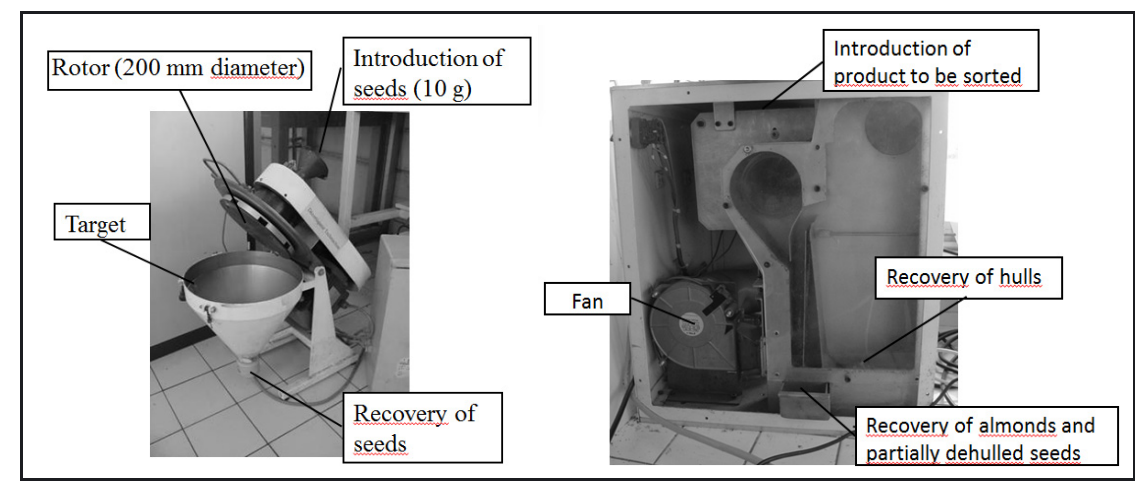

Fig. 1. Pilot dehulling equipment Techmachine (left) and laboratory sorting equipment (right).

we call 'hullability' in this paper, was obtained by measuring the initial weight of the seeds and the weight of extracted hulls: Hullability $(\%)=($ mass of extracted hulls $(\mathrm{g}) \times 100) /($ mass of initial seeds $(\mathrm{g}))$.

Standardised dehulling was performed using laboratory equipment designed to handle small amounts of seeds (5-20 g) and to reproduce the multiple impacts that occur during processing by industrial dehullers. Impacts were obtained by introducing the material into the centre of a centrifuge impeller which propels the seeds against a wall (Fig. 1). The seeds went through the equipment 3 times with a rotational speed of 2000 revolutions per minute (rpm). Following this breaking step, the material was sorted on a small apparatus composed of a rotating screen with $2 \mathrm{~mm}$ perforations, where the small particles called "fines" were removed, and an air column where the large particles were separated into "hull" and "kernel" fractions. The kernel fraction contains partially dehulled seeds as well as pure fractions. The air flow was adjusted to minimise the presence of kernel fragments in the hulls fraction.

Water content plays a significant role in hullability. This being the case, the seeds, because they had been stored at various levels of humidity, were taken out of cold storage and placed in Petri dishes that were then left open for $48 \mathrm{~h}$; this facilitated the equilibration of water content prior to dehulling. The seeds' water content was low, as the seeds had previously been dried slightly in order to aid long-term storage: about 4.5$6.5 \%$ (mean moisture $5.6 \%$, standard deviation $0.74 \%$ ). This moisture was homogeneous enough to allow a comparison of hullability, as seed moisture influences this ability (Sharma et al., 2009).

A conical divider was used to produce from the primary sample four identical subsamples of approximately $15 \mathrm{~g}$. Three replicates were used to in the dehulling test; the fourth was used to measure the seeds' water content. The weighed samples were passed three times in the dehuller at $2000 \mathrm{rpm}$. This method of dehulling was determined by a previous study: it rates as a moderate dehulling.

After a mechanical sorting, the various fractions (kernels, whole seeds, fines and hulls) were weighed (to the nearest $0.01 \mathrm{~g}$ ). The measured percentage of extracted hulls was taken from the average of three replicates. The water content was assessed from the difference in seed weight before and after $15 \mathrm{~h}$ in an oven at $103{ }^{\circ} \mathrm{C}$ (NF V03-909).

Statistical analyses: Data were analyzed using ANOVA. $F$-test and differences were evaluated with Student-Newman-

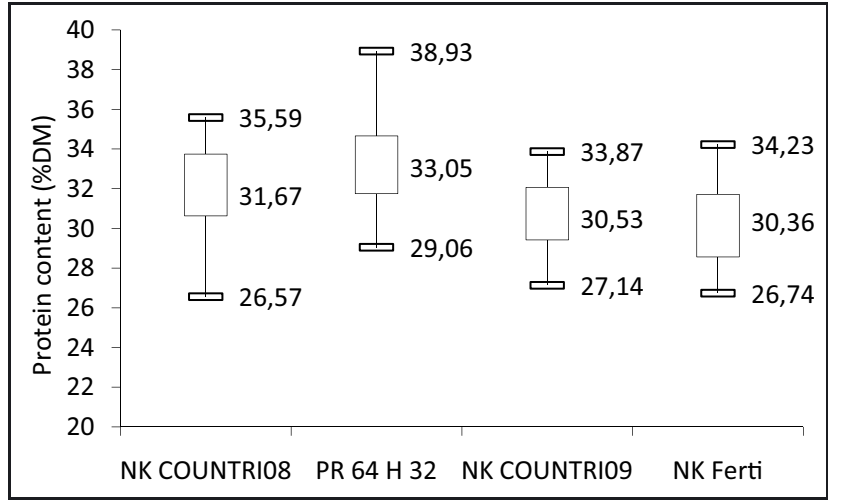

Fig. 2. Boxplots showing the median (bold line in the middle), interquartile range (box) and total range (whiskers) not including atypical values (circle symbols, where they exist) of the seeds' protein content (\% DM).

Keuls test (software SAS Enterprise Guide). The coefficients of determination, and associated probability (Student) were also established using the SAS Enterprise Guide. Shapiro-Wilk tests were performed to check the normality of residuals; homoscedasticity was verified visually.

\section{Results and discussion}

The results for hullability were validated as the seeds' water content displayed only a weak influence on the percentage of extracted hulls $\left(R^{2}=0.0945, p<0.0001\right)$. In this experiment, the seeds' water content varied within a narrow range, from 4.0 to $6.5 \%$.

\subsection{Climatic and genetic effects}

The results presented in Table 1, Figures 2 and 3 indicate both genetic and climatic effects. The climatic effect is revealed by the significant differences for the NK Countri hybrid in 2008 and 2009, concerning oil content (46.2\% vs. $48.4 \%$ of DM respectively), protein content (31.8\% DDM vs. $30.8 \% \mathrm{DDM})$ and hullability ( $23.8 \%$ vs. $19.5 \%$ of extracted hulls). Water stress was much higher in 2009 than in 2008, throughout the growing cycle, especially just before anthesis. This would also explain the difference in the yield of NK Countri, which was much higher in 2008 than in 2009 (2.93 vs. $2.22 \mathrm{t} / \mathrm{ha}$ ). In 2008, there was satisfactory water supply to support sunflower growth from March through to the beginning 
Table 1. Average yearly results for sunflower hybrids from the network of farmers' fields.

\begin{tabular}{|c|c|c|c|c|c|c|c|}
\hline Year & Hybrid & $N$ & $\begin{array}{c}\text { Oil } \\
\text { content } \\
(\% \text { DM })\end{array}$ & $\begin{array}{c}\text { Protein } \\
\text { content } \\
(\% \text { DDM }) \\
\end{array}$ & $\begin{array}{c}\text { Thousand } \\
\text { seeds } \\
\text { weight (g DM) }\end{array}$ & $\begin{array}{c}\text { Hullability } \\
\text { (\% extracted } \\
\text { hulls) }\end{array}$ & $\begin{array}{l}\text { Yield } \\
\text { (t/ha) }\end{array}$ \\
\hline \multirow{2}{*}{2008} & NK Countri & 48 & $48.4(\mathrm{~A})(\mathrm{b}) *$ & 32.1 (A) (b) & $54.5(\mathrm{~A}) *(\mathrm{a}) *$ & 23.4 (A) (a)* & 2.93 (A) (a) \\
\hline & PR64H32 & 48 & $51.8(\mathrm{a})^{*}$ & 33.3 (a) & $53.9(\mathrm{a}) *$ & $9.8(\mathrm{~b})^{*}$ & 2.73 (a) \\
\hline \multirow{2}{*}{2009} & NK Countri & 33 & 46.2 (B) (b) & 30.78 (B) (a) & $53.0(\mathrm{~A}) *(\mathrm{a}) *$ & 19.5 (B) (a) & $2.22(\mathrm{~B})(\mathrm{a})$ \\
\hline & NK Ferti & 41 & 49.6 (a) & 30.3 (a) & $42.7(b)^{*}$ & $14.2(\mathrm{~b})$ & 2.22 (a) \\
\hline
\end{tabular}

Means within a column followed by the same letter are not significantly different $(P<0.05)$ with Student comparison test, except $*$ with Wilcoxon signed rank test. Capital letters (A, B) compare the years for the NK Countri hybrid. Small letters (a, b) compare the hybrids within a year. $\mathrm{SD}=$ Standard Deviation.

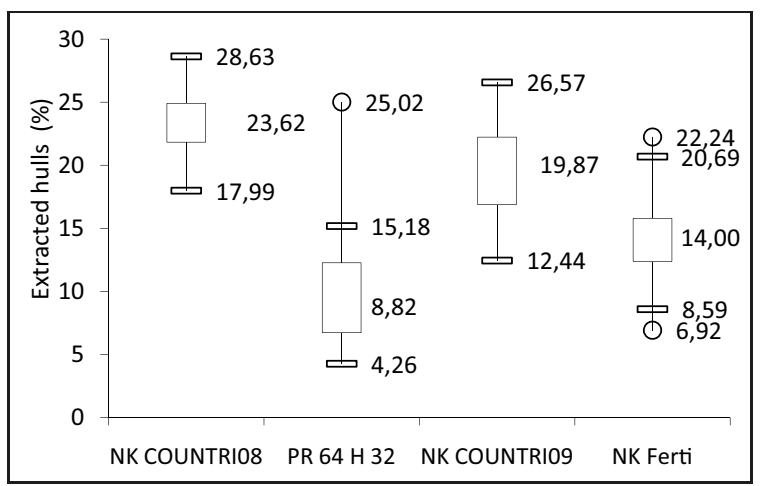

Fig. 3. Boxplots showing the median (bold line in the middle), interquartile range (box) and total range (whiskers) not including atypical values (circle symbols, where they exist) of the seeds' hullability $(\%)$.

of July; water stress then occurred after flowering, which may have improved hullability, as well as protein content. Indeed, it was observed that water stress, in particular during seed maturation, resulted in a considerable increase in hullability and these results confirm previous studies showing an environmental effect on hullability (Beauguillaume et al., 1992; Denis and Vear, 1994; Merrien et al., 1992; Nel, 2001). Oil and protein content could also be influenced by water stress and variety (Oraki et al., 2011), the oil and protein contents being higher in 2008, the year with a better water supply and yield.

A genetic effect was demonstrated. The NK Countri hybrid produced a lower oil content than the PR64H32 and NK Ferti hybrids. PR64H32 had higher protein content than NK Countri (a difference of 1.5 points), while there was no significant difference between NK Countri and NK Ferti for this parameter. For protein content, within a single variety, differences between locations ranged from 7 to 10 points, showing that soil and climate conditions had greater effect than the genetic effect.

Regarding hullability, for a single variety, differences between locations ranged from 10 to 14 points of extracted hulls, showing that soil and climate conditions had an effect equivalent to the genetic effect. NK Countri showed a good dehulling propensity, 4.3 points higher than that of NK Ferti and 13.6 points higher than PR64H32.

As for the size of seeds, expressed by the Thousand Seeds Weight (g DM), there was no significant difference between NK Countri and PR64H32; both were significantly larger than NK Ferti.

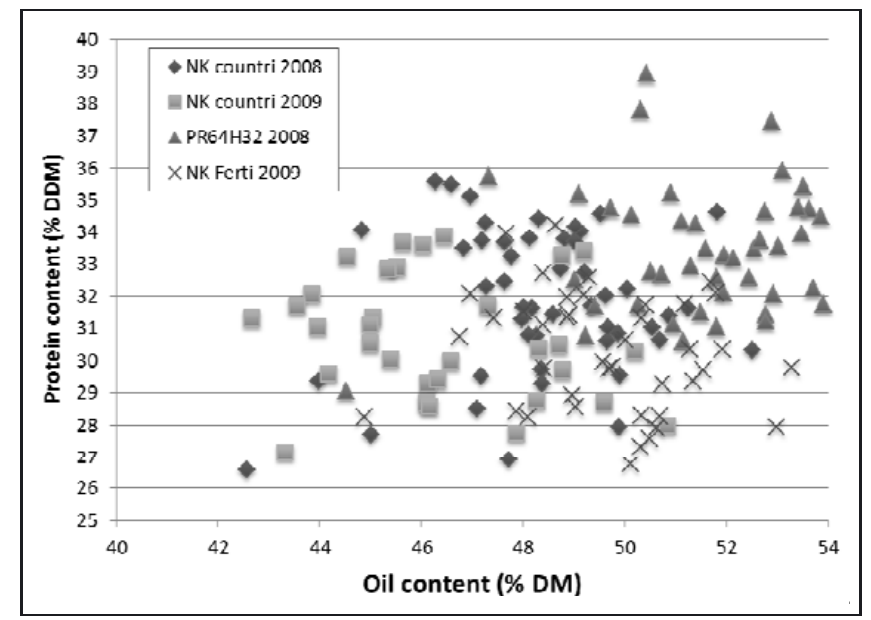

Fig. 4. Relationship between seed protein content (\% DDM) and oil content of 4 sunflower varieties.

Regarding oil content, significant differences were observed between varieties. PR64H32 and NK Ferti were respectively 3.4 points and 3 points higher than NK Countri.

\subsection{Relations between protein and oil contents, and hullability}

No relationship was observed between protein content expressed as a proportion of DDM and oil content (Fig. 4), but there was a significant negative linear relationship between hullability and oil content (Tab. 2). This could explain the differences in degrees of hullability between varieties, as NK Countri was the variety with the lowest oil content and the greatest hullability. This negative linear relationship between hullability and oil content has been observed by other authors (Denis et al., 1994, de Figuereido et al., 2011).

We examined relationships between other parameters - nitrogen fertilization, yield, potential of the soils, number of seeds per $\mathrm{m}^{2}$, weight per seed - and protein content and hullability. Due to the wide range of situations and agricultural practices encountered in the farmers' fields, none could be shown to influence significantly both parameters. Nevertheless, an influence has been shown in experiments under controlled conditions by other authors (for example Nel, 2001), particularly for nitrogen fertilization: increasing nitrogen supply to a sunflower crop led to a higher seed protein content (\% DDM), as well as lower oil content, especially when this nitrogen supply exceeded the crop's needs. 
Table 2. Regression equations for hullability (\% extracted hulls) as a function of oil content (\% DM).

\begin{tabular}{ccccc}
\hline Year & Hybrid & Regression equation & $R^{2}$ & $p$ \\
\hline \multirow{2}{*}{2008} & NK Countri & $-0.68 *$ OC +56.30 & 0.324 & $<0.0001$ \\
& PR64H32 & $-1.61 *$ OC +93.52 & 0.594 & $<0.0001$ \\
\multirow{2}{*}{2009} & NK Countri & $-1.44 *$ OC +86.26 & 0.782 & $<0.0001$ \\
& NK Ferti & $-1.04 *$ OC +65.54 & 0.339 & $<0.0001$ \\
\hline
\end{tabular}

OC: oil content (\% DM).

\section{Conclusion}

This study shows that both the protein content of sunflower seeds (\% DDM) and their hullability are influenced by the environment, climate having a substantial effect. Depending on its intensity and the timing of its occurrence, water stress has an influence on the development of the plants, modifying the grain composition and the seeds' size, which has consequences for protein content and hullability. The plant's genes were also shown to affect protein content and hullability. Oil content influenced hullability, but no relationship was observed between oil content and protein content (\%DDM).

In this study, which was conducted across a large number of farmers' fields, the influence of agricultural practices such nitrogen fertilization could not be established. Attempting to improve seed quality for the purpose of dehulling by modifying agricultural practices would therefore appear to be rather challenging.

At present, breeding programs do not take into account criteria such as protein content and hullability. Crushers must adapt their dehulling equipment. Hybrids can however be produced that offer an increase in protein content without a negative effect on the oil content, such as the hybrid PR64H32 which delivered higher protein and oil contents than NK Countri. Increasing the protein content of sunflower seeds through breeding would help to improve meal quality and the profitability of the crushing process over the longer term. Genetically enhancing the oil content of sunflower seeds might impact negatively on hullability; it could be worthwhile verifying this in order to avoid difficulties at the crushing plants.

Acknowledgements. The authors acknowledge IN VIVO AgroSolutions, ARTERRIS, Val de Gascogne and the funding by the CASDAR of the French Ministry of Agriculture, Food and Fisheries.

\section{References}

Beauguillaume A, Evrard J, Merrien A. 1992. Variété ou milieu, quelles influences sur le décorticage? Oléoscope 12: 16-17.

Borredon ME, Berger M, Dauguet S et al. 2011. Débouchés actuels et futurs du tournesol produit en France Critères de qualité. Innov. Agron. 14: 19-38.
Dauguet S, Peyronnet C, Merrien A, Krouti M, Loison JP, Quinsac A. 2012a. A multi-year survey on sunflower meal quality produced in France. In: Proc. 18th Int. Sunfl. Conf., Mar del Plata, Argentina. Paris, France: Int. Sunfl. Assoc.

Dauguet S, Guillemain C, Carré P, Merrien A, Krouti M, Champolivier L. 2012b. Effect of sunflower seeds quality on dehulling process in order to produce protein content guaranteed meal. In: Proc. 18th Int. Sunfl. Conf., Mar del Plata, Argentina. Paris, France: Int. Sunfl. Assoc.

Denis L, Vear F. 1994. Environmental effects on hullability of sunflower hybrids. Agronomie 14:589-597.

Denis L, Dominguez J, Baldini M, Vear F. 1994. Genetical studies of hullability in comparison with other sunflower seed characteristics. Euphytica 79: 29-38.

Evrard J, Burghart P, Carré P, et al. 1996. Improvement of sunflower dehulling ability an interdisciplinary approach. In: Proc. 14th Int. Sunfl. Conf., Beijing/Shenyang, China. Paris, France: Int. Sunfl. Assoc.

Figueiredo (de) AK, Baümler E, Riccobene IC, Nolasco SM. 2011. Moisture-dependent engineering properties of sunflower seeds with different structural characteristics. J. Food Eng. 102:58-65.

Merrien A, Dominguez J, Vannozzi GP, Baldini M, Champolivier L, Carré P. 1992. Factors affecting the dehulling ability in Sunflower. In: Proc. 13th Int. Sunfl. Conf., Pisa, Italy. Paris, France: Int. Sunfl. Assoc.

Nel AA. 2001. Determinants of sunflower seed quality for processing. Ph.D. diss. Univ. of Pretoria, Pretoria, Republic of South Africa. Available from http://upetd.up.ac.za/thesis/ available/etd-09012001-132144/.

Oraki H, Alahdadi I, Parhizkar khajani F. 2011. Influrence of water deficit and genotype on protein, oil contents and some physical characteristics of sunflower seeds. Afr. J. Agric. Res. 6: 12461250.

Peyronnet C, Pressenda F, Quinsac A, Carré P. 2012. Impact du décorticage du tournesol sur la valeur nutritionnelle et l'intérêt économique des tourteaux en fabrication d'aliments composés. OCL 19: 341-346.

Sharma R, Sogi DS, Saxena DC. 2009. Dehulling performance and textural characteristics of unshelled and shelled sunflower (Helianthus annuus L.) seeds. J. Food Eng. 92: 1-7.

Tostain S, Chervier P, Laulan A, Kermorgant T. 2012. Amélioration de l'autonomie énergétique et de l'impact environnemental d'une unité de trituration de tournesol par l'implantation conjointe d'un atelier de décorticage et d'une chaudière à coques. OCL 19: 332340 .

Cite this article as: Sylvie Dauguet, Frédéric Fine, Céline Guillemain, Patrick Carré, André Merrien, Mohammed Krouti, Luc Champolivier. Impact of pedoclimatic and agricultural conditions on sunflower seeds characteristics in relation to the dehulling process. OCL 2015, 22(4) D402. 